\title{
Characterization of Brachiaria decumbens 'Basilisk' pasture subjected to flexible grazing by sheep
}

\author{
Jefte A. de A. Conrado ${ }^{1 *}$, Marcos N. Lopes ${ }^{2}$, Magno J.D. Cândido ${ }^{1}$, Clemente F. dos Santos-Neto ${ }^{1}$, \\ Leonardo F. de Morais ${ }^{1}$, Antônia F.F. Torres ${ }^{1}$, Dayanne R. do Nascimento ${ }^{1}$, and Maria S. de S. Carneiro ${ }^{1}$ \\ ${ }^{1}$ Universidade Federal do Ceará, Departamento de Zootecnia, Av. Mister Hull, 2977, Campus do Pici, CEP: 60356-000, Fortaleza, \\ Ceará, Brasil. "Corresponding author (jefte_arnon@hotmail.com). \\ ${ }^{2}$ Instituto Federal do Piauí, Campus Valença do Piauí, Av. Joaquim Manoel, s/n, Centro, Valença do Piauí, CEP: 64300-00, Valença do \\ Piauí, Piauí, Brasil.
}

Received: 8 January 2021; Accepted: 18 March 2021; doi:10.4067/S0718-58392021000300338

\begin{abstract}
The sustainability of animal production on pasture is based on improving the management of forage species used, which ensures increase in animal productivity, pasture perenniality and cost reduction. The objective was to characterize productive, structural, physiological and normalized difference vegetation index (NDVI) responses of Brachiaria decumbens Stapf 'Basilisk' over the flexibilization of the grazing management adopted. Four defoliation combinations were evaluated, which consisted of the arrangement of two (85\% and 95\%) light interceptions (LI) and two (1.3 and 1.8) residual leaf area indexes (RLAI), as parameters of entry and exit of the animals from the pasture, respectively. Higher total forage biomass was observed (TFB, $\mathrm{kg} \mathrm{DM} \mathrm{ha}^{-1}$ ) $18.82 \%$, when the canopy was managed at the lowest defoliation frequencies (95\% LI), but with a higher morphological composition of the stem component and dead material. The $95 \%$ LI produced an extra layer of leaves than the canopy managed at $85 \%$ LI. The physiological variables were affected by the higher frequency of defoliation $(85 \% \mathrm{LI})$, with lower photosynthetic rates. NDVI was higher in the canopy managed in the pre-grazing condition at $95 \% \mathrm{LI}(0.88)$ and residual condition at $1.8 \mathrm{RLAI}(0.49)$, when compared to $85 \% \mathrm{LI}(0.86)$ and 1.3 RLAI (0.44). For greater production per animal, managing at $85 \% \mathrm{LI} \times 1.8 \mathrm{RLAI}$ with pre-grazing and residual NDVI of 0.85 and 0.49 , respectively, is the most suitable while for greater animal production per area, managing at $95 \%$ LI $\times 1.3$ RLAI with pre-grazing and residual NDVI of 0.88 and 0.44 , respectively, becomes more efficient.
\end{abstract}

Key words: Forage production, forage structure, leaf area index, NDVI, photosynthesis, rotational stocking.

\section{INTRODUCTION}

In tropical regions, pasture-based animal production has become the most economical and profitable way, in addition to the fact that those areas provide other global environmental services, such as: $\mathrm{C}$ capture in the soil serving as a habitat for life (Sollenberger et al., 2019), thus contributing to the production of food on the planet and the conservation of the environment.

In Brazil, the intensification of these areas began in the 1970s, when the genus Brachiaria boosted national livestock (Rozalino Santos et al., 2014), where from the approximately 170 million of hectares of cultivated pasture areas, $40 \%$ are occupied by this genus (Martuscello et al., 2011). Of all the species of this genus, the most grown cultivar throughout the national territory is Basilisk, popularly known as brachiarinha. Its rapid diffusion and acceptability were mainly due to its high adaptability to acid soils, resistance to grazing, good DM yield $\left(\mathrm{kg} \mathrm{ha}^{-1}\right)$ (Pereira et al., 2018), and its growth habit (decumbent) that guarantees good soil coverage (Rozalino Santos et al., 2014). 
Among the production systems adopted in Brazil, the rotational stocking method stands out as it presents a greater possibility of local control (plant and animal). According to Pedreira et al. (2017), the first criterion used to determine the rest period was fixed days, but it was classified later as inefficient, since the rate of forage accumulation is irregular during the year, due to the seasonality of pasture production.

In order to improve the efficiency of use of tropical forage species in the world, studies have signaled in the last decade (Zanini et al., 2012; Silva et al., 2015a; Pedreira et al., 2017) that reaching a 95\% of light interception (LI) and a residual leaf area index (RLAI) of 1.0 (Pompeu et al., 2008), would be the ideal moments to respectively start and end grazing under rotational stocking.

On the other hand, Miqueloto et al. (2019) described the possibility of flexibilization in the management goals adopted, especially in tropical regions, as there are more favorable periods of time for forage production than others, and the exit of the grazing area would be based on both residual biomass and its structure (morphological composition) (Zanini et al., 2012; Silva et al., 2015a). Gomide et al. (2007) already indicated that an RLAI greater than 1.0 and lesser than 2.0 would be ideal, as it would be able to boost the rapid recovery of the canopy, due to the production of photoassimilates, without compromising its continuity and quality. However, Carvalho (2013) proposed to reduce the frequency of 95\% LI to values close to $85 \%$ and $90 \%$, which would boost and potentiate the allowed intake speed in a constant way, mitigating senescence losses, canopy stem elongation, and favoring higher density of nutrients consumed by the animal (Martins et al., 2020) and a greater accumulation of forage.

Therefore, it is necessary to consider the need to characterize the productive, structural and physiological responses of this species when defoliated by small animals such as sheep, given the few studies developed (Rozalino Santos et al., 2014; Pedreira et al., 2017), and its importance in tropical environments, since most were developed under clipping (plots). In addition to the mophophysiological aspects, there are no information regarding the use of remote sensing as a management tool in cultivated pasture areas, with the normalized difference vegetation index (NDVI), proposed by Rouse et al. (1973), which has an important relationship with these parameters, being an important methodology to be tested, considering its practicality and speed of use, favoring the management process of the production system.

In view of the above, it is hypothesized that the species Brachiaria decumbens Stapf 'Basilisk, has high phenotypic plasticity, modifying its architecture as well as its physiological aspects. This is a reflection of the purpose of the activity (gains per animal or area), as the defoliation frequency range of $85 \%$ to $95 \%$ LI associated to an RLAI above 1.0 (range between 1.3 to 1.8 ) is a management range that will ensure greater sustainability and productivity to the system, according to its objective. Therefore, the aim of this study was to quantify and characterize productive, physiological, NDVI, and structural aspects of Brachiaria decumbens 'Basilisk', with the flexibilization of the grazing management goals using sheep, both in residual and pre-grazing conditions, under rotational stocking, in order to direct the most appropriate management according to the objective of each production system.

\section{MATERIAL AND METHODS}

\section{Characterization of the area and period of the study}

The experiment was carried out at the Nucleus of Education and Studies in Forage Crops, in the Animal Science Department of the Agricultural Sciences Center of the Federal University of Ceará (UFC), located in Fortaleza ( $03^{\circ} 45^{\prime} 47^{\prime \prime}$ S, 38 31' $23^{\prime \prime}$ W; 21 m a.s.1.), Ceará, Brazil, following the ethical standards and approved by the Ethics Committee for the Use of Animals (Protocol Nr 80/17). The research lasted approximately 584 d (August 2018 to April 2020), having gone through two dry and two rainy seasons. The climate in Fortaleza is characterized as rainy tropical Aw', according to Köppen-Geiger (Peel et al., 2007). The rainfall data and current temperature (maximum and minimum) of the experimental and historical period were collected at the UFC's weather station, located $0.5 \mathrm{~km}$ from the experimental area (Figure 1).

The species used was Brachiaria decumbens Stapf (syn. Urochloa decumbens (Stapf) R.D. Webster) 'Basilisk'. It was sown in Yellow Argisol with sandy texture (Santos et al., 2018), in a total area of $1400 \mathrm{~m}^{2}$, divided into 16 paddocks of $12.5 \times 7.0 \mathrm{~m}\left(87.5 \mathrm{~m}^{2}\right)$. The experimental area had a fixed low-pressure sprinkler irrigation system equivalent to an operating pressure of $<2.0 \mathrm{kgf} \mathrm{cm}{ }^{-2}$, with flow rate of $0.8 \mathrm{~m}^{3} \mathrm{~h}^{-1}$ and a fixed daily amount of water of $7 \mathrm{~mm} \mathrm{~h}^{-1}$. The irrigation time was $40 \mathrm{~min}$ in the dry season whereas in the rainy season it was complementary, always carried out late afternoon. The area was grazed by 30 Morada Nova sheep $(35 \mathrm{~kg} \pm 4.0)$ in a period ranging from 10 to $12 \mathrm{~h}$, aiming at a fast and intense grazing, characterized as mob-grazing (Gildersleeve et al., 1987). 
Figure 1. Current precipitation and maximum and minimum temperatures (Max. and Min. Temp.) of the experimental period (2018, 2019 and 2020) and historical (1989-2017) (Hist. Prec., Hist. Max. and Hist. Min. Temp.), respectively from the experimental area.

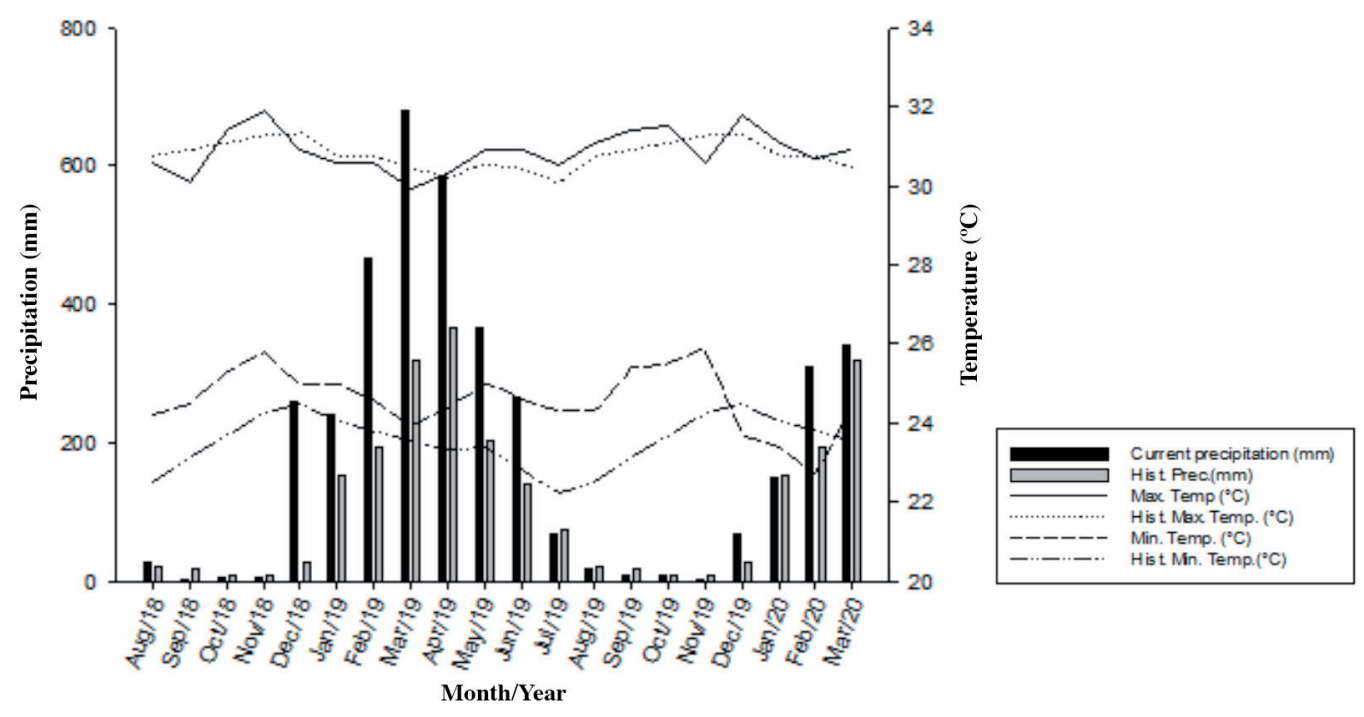

Two soil samplings (17 January 2018 and 15 January 2019) were carried out in order to monitor its fertility during the experimental period. Samples were collected at a depth of 0 to $20 \mathrm{~cm}$ from the ground level, and sent to the UFC's Soil Science Laboratory. The results revealed for year 2018: $\mathrm{pH} 6.80,11.17 \mathrm{~g}$ organic matter (OM) $\mathrm{kg}^{-1}, 285.0 \mathrm{mg} \mathrm{P} \mathrm{dm}^{-3}$, $136.85 \mathrm{mg} \mathrm{K} \mathrm{dm}{ }^{-3}, 1.60 \mathrm{cmol}_{\mathrm{c}} \mathrm{Ca}^{2+} \mathrm{dm}^{-3}, 1.0 \mathrm{cmol}_{\mathrm{c}} \mathrm{Mg}^{2+} \mathrm{dm}^{-3}, 0.20 \mathrm{cmol}_{\mathrm{c}} \mathrm{Al}^{3+} \mathrm{dm}^{-3}$, sum of bases (SB) $3.10 \mathrm{cmol}_{\mathrm{c}} \mathrm{dm}^{-3}$, cation exchange capacity (CEC) $3.60 \mathrm{cmol}_{\mathrm{c}} \mathrm{dm}^{-3}$ and base saturation (V) $86 \%$; and year 2019: $\mathrm{pH} 7.70,5.90 \mathrm{~g} \mathrm{OM} \mathrm{kg}^{-1}$, $26.0 \mathrm{mg} \mathrm{P} \mathrm{dm}{ }^{-3}, 35.19 \mathrm{mg} \mathrm{K} \mathrm{dm}{ }^{-3}, 1.20 \mathrm{cmol}_{\mathrm{c}} \mathrm{Ca}^{2+} \mathrm{dm}^{-3}, 0.80 \mathrm{cmol}_{\mathrm{c}} \mathrm{Mg}^{2+} \mathrm{dm}^{-3}, 0.0 \mathrm{cmol}_{\mathrm{c}} \mathrm{Al}^{3+} \mathrm{dm}^{-3}, \mathrm{SB} 2.70 \mathrm{cmol}_{\mathrm{c}} \mathrm{dm}^{-3}$, CEC $3.0 \mathrm{cmol}_{\mathrm{c}} \mathrm{dm}^{-3}$ and $\mathrm{V} 89 \%$.

After that, the fertilization was carried out according to Alvarez et al. (1999), by applying $20 \mathrm{~kg} \mathrm{ha}^{-1} \mathrm{P}_{2} \mathrm{O}_{5}$ and $200 \mathrm{~kg} \mathrm{ha}^{-1} \mathrm{~K}_{2} \mathrm{O}$, using single superphosphate and potassium chloride fertilizers, respectively, favoring the restitution of the extracted nutrients from the year 2018 to 2019. In addition, 30 and $40 \mathrm{~kg} \mathrm{ha}^{-1}$ of a commercial source (FTE BR 12; Agroadubo, São José do Rio Preto, São Paulo, Brasil) were also applied, in order to supply the demand for micronutrients, in the years 2018 and 2019, respectively. A N fertilization was also maintained, equivalent to $600 \mathrm{~kg} \mathrm{ha}^{-1} \mathrm{yr}^{-1}$, applied as urea $\left(\mathrm{CH}_{4} \mathrm{~N}_{2} \mathrm{O}\right.$, with $\left.45 \% \mathrm{~N}\right)$ during the growth cycle of the plants.

\section{Treatments and experimental design}

The design adopted was completely randomized with the experimental scheme organized in a factorial arrangement $(2 \times 2)$, where the treatments consisted of a combination of two defoliation frequencies and two defoliation intensities, resulting in four treatments. They were studied in both residual and pre-grazing conditions. The frequencies were based on $85 \%$ and $95 \%$ light interception (LI) of the photosynthetically active radiation (PAR), and on intensities of 1.3 and 1.8 of residual leaf area indexes (RLAI) of the canopy.

\section{Total biomass, structural, physiological and NDVI variables}

To determine the RLAI and LI, a PAR-LAI analyzer (Accupar LP-80, Decagon Devices, Pullman, Washington, USA) was used. The readings were taken at least 15 times per experimental unit in the upper and lower parts of the canopy, between 10:00 and 12:00 $\mathrm{h}$. The evaluations were carried out weekly in the pre-grazing condition and hourly in the residual condition, in order to detect the recommended management goals.

The physiological variables data were collected only in the pre-grazing condition, the variables were: photosynthetic rate $\left(\mathrm{A}, \mu \mathrm{mol} \mathrm{CO}_{2} \mathrm{~m}^{-2} \mathrm{~s}^{-1}\right)$, transpiration rate $\left(\mathrm{E}, \mathrm{mmol} \mathrm{H}_{2} \mathrm{O} \mathrm{m}^{-2} \mathrm{~s}^{-1}\right)$, stomatal conductance $\left(\mathrm{G}_{\mathrm{s}}, \mathrm{mol} \mathrm{m}^{-2} \mathrm{~s}^{-1}\right)$, internal

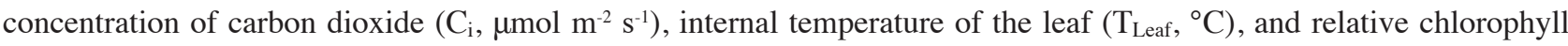
index (RCI). To collect that data, two equipment were used: an infrared gas exchange analyzer (IRGA LC-Pro-SD, ADC Bioscientific Ltd., Hoddesdon, Hertfordshire, UK) under constant light intensity (2000 $\mu \mathrm{mol}$ photons $\left.\mathrm{m}^{-2} \mathrm{~s}^{-1}\right)$ and a 
chlorophyll meter (SPAD-502Plus, Konica Minolta, Tokyo, Japan). The measures were taken on the last newly expanded leaf, in a minimum of five times per experimental unit, from 10:00 to 12:00 h.

The normalized difference vegetation index (NDVI) was measured using an active optical sensor (AOS) (GreenSeeker handheld crop sensor, Trimble, Sunnyvale, California, USA), both in the residual and pre-grazing condition. The sensor takes readings between 0.6 to $1.2 \mathrm{~m}$ from the height of the "target", with a field of view ranging from 25 to $50 \mathrm{~cm}$, with a capacity of 1000 readings per second, eliminating the effect of the environment, since it has emission diodes of its own radiation, in the bands of red $(650 \mathrm{~nm})$ and near infrared $(770 \mathrm{~nm})$. NDVI was proposed by Rouse et al. (1973) to analyze biophysical characteristics of vegetations (Equation 1), based on the spectral response of the canopy in two bands: infrared (Rnir, 700 and $1300 \mathrm{~nm}$ ) and red (Rred, 550 and $700 \mathrm{~nm}$ ) (Kumar and Silva, 1973):

$$
\text { NDVI }=\text { Rnir }- \text { Rred/Rnir }+ \text { Rred }
$$

The variables of structural nature, evaluated in the residual and pre-grazing conditions, were: canopy height $(\mathrm{CH}$, $\mathrm{cm}$ ) and leaf/stem ratio (L/S), with tiller population density (TPD, tiller $\mathrm{m}^{-2}$ ) and number of new leaves produced (NLP, leaf tiller ${ }^{-1}$ ) measured only in the pre-grazing condition. The vertical structure of the canopy was also evaluated, through the distribution of morphological components of forage biomass, for this, the methodology of the inclined point quadrat (Wilson, 1960) was used, in both residual and pre-grazing conditions. Each component, when touched, was identified, and the height was recorded from the touch. After each touch, the component was carefully moved to the side, so that the stem continued its descent and touched the other components until it reached the surface of the soil. A minimum of 100 touches were performed per experimental unit, which produced a variation in the readings in each season according to the different heights and volumes of forage. Data were organized and tabulated in a processed spreadsheet, where the number of rings of each specific component was transformed into a percentage of the total number of rings in each stratum.

To determine the TPD, a frame $(42 \times 30 \mathrm{~cm})$ was placed at random in the experimental unit, with all the tiller inside being counted. For the variable NLP, 15 tillers per experimental unit were used so that all expanded leaves above the last grazed were counted, calculating the arithmetic mean.

The total biomass variables were evaluated in the residual and pre-grazing conditions: total forage biomass (TFB, $\mathrm{kg} \mathrm{DM} \mathrm{ha}^{-1}$ ) and its fractions, green leaf blade (GLB, $\mathrm{kg} \mathrm{DM} \mathrm{ha}^{-1}$ ), green stem (GSB, $\mathrm{kg} \mathrm{DM} \mathrm{ha}^{-1}$ ) and dead forage (DFB, $\left.\mathrm{kg} \mathrm{DM} \mathrm{ha}^{-1}\right)$.

In order to harvest the biomass, a frame of known area $(42 \times 30 \mathrm{~cm})$ was used, colecting all the material close to the soil, using pruning scissors. After that, the biomass was fractionated into leaves, stem and dead forage, weighed and taken to the ventilation oven with forced air circulation at $55^{\circ} \mathrm{C}$ until it reached constant weight, and weighed again to obtain the dry weight. The moment when the highest leaf promoted a curvature, was counted, to measure the $\mathrm{CH}$, using a retractable graduated stick type sward stick (Barthram, 1986).

\section{Statistical analysis}

Data were subjected to analysis of normality by the Kolmorogov-Smirnov test $(\mathrm{P}<0.05)$ and homoscedasticity, which was verified through graphical visualization of the residues. When the assumptions were met, the following model was adopted: $Y_{\mathrm{ijk}}=\mu+\alpha_{\mathrm{i}}+\beta_{\mathrm{j}}+\delta_{\mathrm{k}}+Æ_{\mathrm{m}}+\AA_{\mathrm{n}}+(\propto \beta)_{\mathrm{ij}}+(\propto \beta Æ)_{\mathrm{ijm}}+\varepsilon_{\mathrm{ijkmn}}$. Where $\mathrm{Y}_{\mathrm{ijk}}$ is the dependent variable, $\mu$ is the general average, $\alpha_{\mathrm{i}}$ is the fixed effect of the frequency, $\beta_{\mathrm{j}}$ is the fixed effect of the intensity, $\delta_{\mathrm{k}}$ is the random effect of the cycle, $Æ_{\mathrm{m}}$ is the fixed effect of the season, $\hat{\AA}_{\mathrm{n}}$ is the random effect of the year, $(\propto \beta)_{\mathrm{ij}}$ is the effect of the Frequency $x$ Intensity interaction, $(\alpha \beta Æ)_{\mathrm{ijm}}$ is the effect of the Frequency $\times$ Intensity $\times$ Time interaction, and $\varepsilon_{\mathrm{ijkmn}}$ is the effect of the random error, thus assuming an independent normal distribution. For this, the PROC MIXED procedure was used, with LSMEANS as a way to perform multiple comparisons of the effects of the tests, through the Tukey-Kramer at 5\% of probability, from the software SAS University Edition (SAS Institute, Cary, North Carolina, USA).

\section{RESULTS AND DISCUSSION}

There was a significant difference $(\mathrm{P}<0.05)$ for the TFB variable, in the residual condition, with the lowest frequency (95\% LI) being the one with the highest production. This increase is due to, among other factors, the higher mean residual LAI (1.51) found, for this frequency. This aspect can be understood by looking at the components of the harvested biomass, which at an intensity of 1.8 (regardless of the grazing frequency), promoted increases in the order of $64.34 \%$, $11.18 \%$ and $27.68 \%$ for GSB, DFB and GLB, respectively, when compared to a higher defoliation intensity (1.3 RLAI). 
With the elongation of the rest period, there is an increase in the LAI, which may promote a grown up of the stem fraction, due to self-shading, thus accumulating more DFB and GSB. Despite favoring animal performance in the short term, due to the accumulation of available biomass, these fractions, on the other hand, in the medium and long term, may compromise the structure, reducing the species' longevity (Table 1).

There was a significant effect of frequency $(\mathrm{F})(\mathrm{P}=0.031)$ and intensity $(\mathrm{I})(\mathrm{P}<0.05)$ on the $\mathrm{L} / \mathrm{S}$ ratio, which was $28 \%$ higher in RLAI $1.3(0.83)$ when compared to RLAI $1.8(0.65)$ regardless of the defoliation frequency. When assessing frequency, it was found that when the canopy was managed to intercept $95 \%$ of sunlight, the ratio was $3 \%$ lower than that of $85 \% \mathrm{LI}$ ( 0.76 and 0.74 , respectively). This fact is possibly associated to a higher frequency of defoliation ( $85 \% \mathrm{LI})$, which influenced both the lower growth of tillers and the distribution of leaves along the stem (greater uniformity) of this species of decumbent growth habit. According to Silva et al. (2015a), in contrast to the plants of the cespitous growth habit that present the denser leaf growth in the upper part of the canopy, with the older ones located initially above 5 $\mathrm{cm}$ from the ground level, the ones with decumbent growth have phenotypic plasticity, such as B. decumbens 'Basilisk' (Rozalino Santos et al., 2014; Gastal and Lemaire, 2015).

Table 1. Total forage biomass, its fractions, structural and spectral characteristics of Brachiaria decumbens 'Basilisk' subjected to two frequencies of light interception (85\% and $95 \%$ LI) and two defoliation intensities (1.3 and 1.8 residual leaf area indexes [RLAI]) in the residual condition.

\begin{tabular}{|c|c|c|c|c|c|c|c|}
\hline \multirow{3}{*}{ RLAI } & \multicolumn{7}{|c|}{ Total forage biomass (TFB, kg DM ha-1) } \\
\hline & \multicolumn{2}{|c|}{ LI } & \multirow[b]{2}{*}{ Average } & \multirow[b]{2}{*}{ SEM } & \multicolumn{3}{|c|}{ P-Value } \\
\hline & $85 \%$ & $95 \%$ & & & $\mathrm{~F}$ & I & $\mathrm{F} \times \mathrm{I}$ \\
\hline 1.3 & 1886 & 2057 & 1961B & & & & \\
\hline 1.8 & 2631 & 2713 & $2672 \mathrm{~A}$ & 126.88 & $<0.0001$ & $<0.0001$ & 0.0707 \\
\hline \multirow[t]{2}{*}{ Average } & $2249 b$ & $2385 \mathrm{a}$ & & & & & \\
\hline & \multicolumn{7}{|c|}{ Green leaf blade biomass (GLB, kg DM ha-1) } \\
\hline 1.3 & 613.83 & 610.29 & $612 B$ & & & & \\
\hline 1.8 & 795.05 & 767.97 & $781 \mathrm{~A}$ & 123.33 & 0.3723 & $<0.0001$ & 0.4923 \\
\hline \multirow[t]{2}{*}{ Average } & $704.44 \mathrm{a}$ & $689.13 \mathrm{a}$ & & & & & \\
\hline & \multicolumn{7}{|c|}{ Green stem biomass (GSB, $\mathrm{kg} \mathrm{DM} \mathrm{ha}^{-1}$ ) } \\
\hline 1.3 & 741 & 724.5 & 733 & & & & \\
\hline 1.8 & 1194 & 1214.0 & $1204 \mathrm{~A}$ & 47.12 & 0.9537 & $<0.0001$ & 0.4116 \\
\hline \multirow[t]{2}{*}{ Average } & $968 \mathrm{a}$ & $969 \mathrm{a}$ & & & & & \\
\hline & \multicolumn{7}{|c|}{ Dead forage biomass (DFB, $\mathrm{kg}$ DM ha') } \\
\hline 1.3 & $514 \mathrm{Bb}$ & $725 \mathrm{Aa}$ & 619 & & & & \\
\hline 1.8 & $664 \mathrm{Ab}$ & 733Aa & 689 & 47.29 & $<0.0001$ & 0.0002 & 0.0009 \\
\hline \multirow[t]{2}{*}{ Average } & 579.48 & 729 & & & & & \\
\hline & \multicolumn{7}{|c|}{ Leaf/Stem ratio $(\mathrm{L} / \mathrm{S})$} \\
\hline 1.3 & 0.83 & 0.84 & $0.83 \mathrm{~A}$ & & & & \\
\hline 1.8 & 0.68 & 0.64 & $0.65 \mathrm{~B}$ & 0.14 & 0.0311 & $<0.0001$ & 0.5862 \\
\hline \multirow[t]{2}{*}{ Average } & $0.76 \mathrm{a}$ & $0.74 \mathrm{~b}$ & & & & & \\
\hline & \multicolumn{7}{|c|}{ Leaf area index (LAI) } \\
\hline 1.3 & 1.25 & 1.28 & $1.26 \mathrm{~B}$ & & & & \\
\hline 1.8 & 1.71 & 1.75 & $1.73 \mathrm{~A}$ & 0.14 & 0.0004 & $<0.0001$ & 0.5871 \\
\hline \multirow[t]{2}{*}{ Average } & $1.48 \mathrm{~b}$ & $1.51 \mathrm{a}$ & & & & & \\
\hline & \multicolumn{7}{|c|}{ Canopy height $(\mathrm{CH}, \mathrm{cm})$} \\
\hline 1.3 & $10 \mathrm{Bb}$ & $11 \mathrm{Bb}$ & 10 & & & & \\
\hline 1.8 & $14 \mathrm{Ab}$ & $15 \mathrm{Aa}$ & 14 & 0.24 & $<0.0001$ & $<0.0001$ & 0.0153 \\
\hline \multirow[t]{2}{*}{ Average } & 12 & 13 & & & & & \\
\hline & \multicolumn{7}{|c|}{ Normalized difference vegetation index (NDVI) } \\
\hline 1.3 & 0.43 & 0.45 & $0.44 \mathrm{~B}$ & & & & \\
\hline 1.8 & 0.49 & 0.49 & $0.49 \mathrm{~A}$ & 0.0067 & 0.003 & $<0.0001$ & 0.0942 \\
\hline Average & $0.46 b$ & $0.47 \mathrm{a}$ & & & & & \\
\hline
\end{tabular}

Means followed by distinct lowercase in the rows and uppercase letters in the columns differ according to the Tukey's test $(\mathrm{P}<0.05)$.

F: Frequency; I: intensity; SEM: standard error of the mean of F $\times$ I. 
There is a greater tendency for faster and more vigorous regrowth when the pasture is managed with a higher RLAI, as was the case of what was proposed in this experiment (1.8), which reached the goal of 1.73. Associated with this performance is the low mobilization of organic reserves due to the high LAI (Brougham, 1956), since leaf blades are the tissues with the greatest photosynthetic potential of the canopy (Martuscello et al., 2011). Lenient pastures, which do not exceed $40 \%$ to $50 \%$ margin of pre-grazing material removal, tend to maximize the speed of ingestion of the forage offered (Fonseca et al., 2012) without causing a reduction in the pasture carrying capacity (Zanini et al., 2012).

Significant effect of $\mathrm{F} \times \mathrm{I}$ interaction $(\mathrm{P}=0.0153)$ was observed on the height variable, with the canopy managed at RLAI 1.3 and 1.8, presenting the height 10.98 and $14.90 \mathrm{~cm}$, respectively. This difference was reflected in the NDVI result, where the canopy managed more intensively (RLAI 1.3) regardless of the frequency, showed a lower value (11.36\%) than the RLAI 1.8. This variable was proposed by Rouse et al. (1973), and currently stands out all over the world, due to the efficiency of monitoring the instantaneous condition of the vegetation, and for having a close relationship with the morphophysiological variables (Andersson et al., 2017).

The managements $85 \% \mathrm{LI} \times 1.3 \mathrm{RLAI}$; $85 \% \mathrm{LI} \times 1.8 \mathrm{RLAI}$; 95\% LI $\times 1.3 \mathrm{RLAI}$ and $95 \% \mathrm{LI} \times 1.8 \mathrm{RLAI}$, presented residual heights of $43 \%, 59 \%, 35 \%$ and $45 \%$ of the pre-grazing heights, respectively, which also represented different removal intensities, in the order of 57\%, 41\%,65\% and 55\%, respectively. These values are close to those recommended by Zanini et al. (2012) and Silva et al. (2015a), who described that the residual height should remain between $40 \%$ and $60 \%$ of the pre-grazing height, which allows a greater biomass production of the leaf fraction, favoring the removal by the animal. In the pre-grazing condition, only the variable TPD had significant effect of the $\mathrm{F} \times \mathrm{I}$ interaction $(\mathrm{P}=0.0385)$.

There was a significant difference $(\mathrm{P}<0.05)$ for $\mathrm{TFB}$, reflecting an increase of $18.82 \%$ when the canopy was defoliated at $95 \%$ LI, when compared to $85 \%$ LI. Only effect of the frequency $(\mathrm{P}<0.05)$ was observed on the variable GLB variable, however, there was a difference for frequency $(\mathrm{P}<0.05)$, which reflected an increase of $16.34 \%$ in this fraction and $22.20 \%$ and $19.79 \%$ in the GSB and DFB fractions $(\mathrm{P}<0.05)$, respectively, in the $95 \%$ LI when compared to the $85 \%$ LI management.

The accumulation of these fractions results from both the longer free growth time (without grazing) and the accumulation of thermal radiation that the canopy receives throughout the rest period. According to Sollenberger et al. (2019), when $\mathrm{C}_{4}$ grasses are subjected more intensely to solar radiation and without the presence of any factor (biotic and abiotic) that prevents it from performing, use photons of light through the leaves more efficiently until the critical LAI is close, when thereafter the stem and dead fractions become larger than the leaf fraction, retaining a greater $\mathrm{C}$ supply in the production system.

The differences between the residual management and pre-grazing, resulted in distinct accumulations of biomass $(\mathrm{kg}$ $\mathrm{MS} \mathrm{ha}^{-1}$ ) throughout the growth cycle, being: $1160,1613,1703,2189$, in the managements $85 \% \mathrm{LI} \times 1.8 \mathrm{RLAI}, 85 \% \mathrm{LI}$ $\times 1.3$ RLAI, 95\% LI $\times 1.8 \mathrm{RLAI}$ and $95 \% \mathrm{LI} \times 1.3 \mathrm{RLAI}$, respectively. This difference directly impacts the maximum stocking rate of the area, and its determination is important for a correct planning of the production system.

The $\mathrm{L} / \mathrm{S}$ ratio in the pre-grazing condition, had an effect of the intensity $(\mathrm{P}=0.0259)$, with defoliation frequency $95 \%$ LI, showing a $6 \%$ reduction when compared to $85 \%$ LI. With the increase in regrowth age, plants tend to decrease the L/S ratio, reflecting in the leaf weight ratio (LWR), which tends to follow the same response. Some studies (Rozalino Santos et al., 2014; Pereira et al., 2018) showed that when approaching the critical LAI, the tillers of 'Basilisk', direct part of the carbohydrates produced in the leaf fraction, to the supporting organs (such as the stem), resulting in a production of this at the expense of that.

There was a significant effect of the $\mathrm{F} \times \mathrm{I}$ interaction $(\mathrm{P}=0.0385)$ on $\mathrm{TPD}$, with the frequency $85 \%$ LI producing $7 \%$ more tillers than that $95 \%$ LI. This response is a reflection of the size/density compensation law, which according to Fialho et al. (2012) is caused by the low solar radiation on the lower layers of the canopy, reducing germination of basal buds, which impacts tiller density, and that was observed in the management of 95\% LI. Another point to be highlighted was the reduction of TPD in the frequency 95\% LI with RLAI 1.3, when compared to RLAI 1.8, which can signal the greater wear of the plant when using its reserves in a longer period of growth.

Significant effects of the frequency $(\mathrm{P}<0.05)$ and intensity $(\mathrm{P}<0.05)$ were observed on the height and LAI variables (Table 2). The canopy reached 95\% LI with $34.03 \mathrm{~cm}$ height and pre-grazing LAI of 5.01 (regardless RLAI), while $85 \% \mathrm{LI}$ was reached at $24 \mathrm{~cm}$ and LAI of 3.72. It can be seen how the canopy modifies its structure according to the management adopted. According to Rozalino Santos et al. (2014) the dynamics in the growth of forage plants is attributed to magnitudes of defoliation rates, genetic potential of the species, and according to Silva et al. (2015b), to the time of the year, which at a certain moment favors the growth and development of younger or older tillers, which is regulated by the availability of abiotic factors. 
Table 2. Total forage biomass, its fractions, structural and spectral characteristics of Brachiaria decumbens 'Basilisk' subjected to two frequencies of light interception (85\% and 95\% IL) and two defoliation intensities (1.3 and 1.8 residual leaf area indexes [RLAI]) in the pre-grazing condition.

\begin{tabular}{|c|c|c|c|c|c|c|c|}
\hline \multirow{3}{*}{ RLAI } & \multicolumn{7}{|c|}{ Total forage biomass (TFB, $\mathrm{kg} \mathrm{DM} \mathrm{ha}^{-1}$ ) } \\
\hline & \multicolumn{2}{|c|}{ LI } & \multirow[b]{2}{*}{ Average } & \multirow[b]{2}{*}{ SEM } & \multicolumn{3}{|c|}{ P-Value } \\
\hline & $85 \%$ & $95 \%$ & & & $\mathrm{~F}$ & I & $\mathrm{F} \times \mathrm{I}$ \\
\hline 1.3 & 3499 & 4246 & 3873B & & & & \\
\hline 1.8 & 3791 & 4416 & $4104 \mathrm{~A}$ & 163.74 & $<0.0001$ & $<0.0001$ & 0.1226 \\
\hline \multirow[t]{2}{*}{ Average } & $3645 b$ & $4331 \mathrm{a}$ & & & & & \\
\hline & \multicolumn{7}{|c|}{ Green leaf blade biomass (GLB, $\mathrm{kg}$ DM ha ${ }^{-1}$ ) } \\
\hline 1.3 & 1826 & 2154 & $1990 \mathrm{~A}$ & & & & \\
\hline 1.8 & 1901 & 2183 & $2042 \mathrm{~A}$ & 76.27 & $<0.0001$ & 0.0652 & 0.4240 \\
\hline \multirow[t]{2}{*}{ Average } & $1864 b$ & $2169 \mathrm{a}$ & & & & & \\
\hline & \multicolumn{7}{|c|}{ Green stem biomass (GSB, kg DM ha-1) } \\
\hline 1.3 & 1153 & 1455 & 1304B & & & & \\
\hline 1.8 & 1262 & 1496 & $1379 \mathrm{~A}$ & 133.04 & $<0.0001$ & 0.0019 & 0.1521 \\
\hline \multirow[t]{2}{*}{ Average } & $1207 \mathrm{~b}$ & $1476 \mathrm{a}$ & & & & & \\
\hline & \multicolumn{7}{|c|}{ Dead forage biomass (DFB, $\mathrm{kg} \mathrm{DM} \mathrm{ha}^{-1}$ ) } \\
\hline 1.3 & 517 & 635 & $579 \mathrm{~B}$ & & & & \\
\hline 1.8 & 626 & 734 & $680 \mathrm{~A}$ & 44.64 & $<0.0001$ & $<0.0001$ & 0.6630 \\
\hline \multirow[t]{2}{*}{ Average } & $571 \mathrm{~b}$ & $685 \mathrm{a}$ & & & & & \\
\hline & \multicolumn{7}{|c|}{ Leaf/Stem ratio (L/S) } \\
\hline 1.3 & 1.58 & 1.47 & $1.57 \mathrm{~A}$ & & & & \\
\hline 1.8 & 1.52 & 1.45 & $1.52 \mathrm{~A}$ & 0.1060 & 0.0259 & 0.0779 & 0.4394 \\
\hline \multirow[t]{2}{*}{ Average } & $1.55 \mathrm{a}$ & $1.46 \mathrm{~b}$ & & & & & \\
\hline & \multicolumn{7}{|c|}{ Leaf area index (LAI) } \\
\hline 1.3 & 3.67 & 4.90 & $4.29 \mathrm{~B}$ & & & & \\
\hline 1.8 & 3.77 & 5.12 & $4.45 \mathrm{~A}$ & 0.1628 & $<0.0001$ & $<0.0027$ & 0.2324 \\
\hline \multirow[t]{2}{*}{ Average } & $3.72 b$ & $5.01 \mathrm{a}$ & & & & & \\
\hline & \multicolumn{7}{|c|}{ Canopy height $(\mathrm{CH}, \mathrm{cm})$} \\
\hline 1.3 & 24 & 33 & $28 \mathrm{~B}$ & & & & \\
\hline 1.8 & 24 & 33 & $29 \mathrm{~A}$ & 0.2301 & $<0.0001$ & 0.0002 & 0.6362 \\
\hline \multirow[t]{2}{*}{ Average } & $24.35 b$ & $33.56 \mathrm{a}$ & & & & & \\
\hline & \multicolumn{7}{|c|}{ Normalized difference vegetation index (NDVI) } \\
\hline 1.3 & 0.84 & 0.88 & $0.86 \mathrm{~B}$ & & & & \\
\hline 1.8 & 0.85 & 0.89 & $0.87 \mathrm{~A}$ & 0.0031 & $<0.0001$ & 0.0041 & 0.2771 \\
\hline \multirow[t]{2}{*}{ Average } & $0.84 \mathrm{~b}$ & $0.88 \mathrm{a}$ & & & & & \\
\hline & \multicolumn{7}{|c|}{ Tiller population density (TPD, tiller $\mathrm{m}^{-2}$ ) } \\
\hline 1.3 & 977Aa & $886 \mathrm{Ab}$ & 931 & & & & \\
\hline 1.8 & 937Aa & 909Aa & 923 & 29.50 & 0.0001 & 0.5776 & 0.0385 \\
\hline \multirow[t]{2}{*}{ Average } & 957 & 897 & & & & & \\
\hline & \multicolumn{7}{|c|}{ Number new leaves produced (NLP, leaf tiller-1) } \\
\hline 1.3 & 3.17 & 4.08 & $3.63 \mathrm{~A}$ & & & & \\
\hline 1.8 & 3.10 & 4.01 & $3.55 \mathrm{~A}$ & 0.0733 & $<0.0001$ & 0.1197 & 0.9352 \\
\hline Average & $3.14 \mathrm{~b}$ & $4.05 \mathrm{a}$ & & & & & \\
\hline
\end{tabular}

Means followed by distinct lowercase in the rows and uppercase letters in the columns differ according to the Tukey's test $(\mathrm{P}<0.05)$.

F: Frequency; I: intensity; SEM: standard error of the mean of F $\times$ I. 
The NDVI in the pre-grazing condition was influenced by the management factors, with significant effects of frequency $(\mathrm{P}<0.05)$ and intensity $(\mathrm{P}<0.05)$. When the canopy reached 95\% LI, it showed an NDVI higher by $4.76 \%(0.88)$ than $85 \%$ LI (0.84). It was also observed an increase of 0.004 (10/0,04 NDVI) points of NDVI per day in the canopy managed to $95 \%$ LI when compared to $85 \% \mathrm{LI}$, due to the difference of $10 \mathrm{~d}$ (data not shown), existing between each other. The reflectance intensity is due to the energy reflected from the top of the canopy, which in turn is determined by several properties of the plant, among them are the cellular structure and the plant's development stage (anatomical characteristics), which are enhanced by environmental and management factors (Kumar and Silva, 1973). This technology enables quick monitoring in a larger area, facilitating decision making in the production system, mainly because it has a correlation with LAI and canopy height (Andersson et al., 2017).

Frequency had effect on physiological variables $\mathrm{A}, \mathrm{E}, \mathrm{G}_{\mathrm{s}}$ and $\mathrm{RCI}(\mathrm{P}<0.05)$, with $\mathrm{A}$ and RCI being higher in the management of $95 \%$ LI. This growth is due to the higher pre-grazing LAI (Table 2), which was higher than the canopy managed at 85\% LI. This response according to Gomide et al. (2007) is mainly due to the greater accumulation of starch in the leaves, which ends up inhibiting photosynthesis. In a study carried out with $B$. decumbens, Rozalino Santos et al. (2014) identified a reduction in photosynthetic rates with the increase in defoliation frequency, which impacted on the lower rates of leaf (RLE) and stem (RSE) elongation. According to Parsons et al. (1988) and Yasuoka et al. (2017), that fact favors a lower rate of net photosynthesis, because even though the $85 \%$ management may have a higher photosynthetic rate per leaf than the $95 \%$ management, it has a lower leaf area, not having this photosynthesis produced by the leaf impact on the final LAI, which does not favor the production of forage biomass.

Similar response to that of the photosynthetic rate was found in the variable $\mathrm{G}_{\mathrm{s}}(\mathrm{P}<0.05)$. It was observed that the highest pre-grazing LAI $(95 \% \mathrm{IL})$, consequently, has a higher density of photosynthetic enzymes such as RuBisCO (ribulose-1,5-bisphosphate carboxylase/oxygenase), responsible for fixing $\mathrm{CO}_{2}$, through an energizing substrate, ribulose 1,5-bisphosphate (RuBP). The stomatal opening process is due to the stimuli of the day (radiation, temperature, etc.) and morphological changes (such as size, shape and mobility) of a given species (Franklin, 2016; Hussain et al., 2019; Shafiq et al., 2021).

An effect of frequency $(\mathrm{P}=0.038)$ and intensity $(\mathrm{P}=0.0323)$ was observed on $\mathrm{E}$, with the pre-grazing condition of the management of $95 \%$ LI presenting the lowest value when compared to the less lenient grazing (Table 3). Possibly, by raising the physiological age, the plant becomes more efficient in the use of water, reducing its losses due to transpiration, while in frequent defoliation, there is a concentration of $\mathrm{N}$, resulting in a more intense action by RuBisCO. Pezzopane et al. (2015) identified that when intensely grazed, the regrowth of the canopy becomes more dependent on the reserve of carbohydrates, being directed to the leaves, mainly restricting maintenance respiration, preventing transpiration. Kroth et al. (2015) confirmed that when some type of stress occurs (biotic or abiotic) the plants tend to have a higher concentration of reducing sugars (RSs) in the leaves, reducing the translocation via phloem to the roots, where they would be fundamental in maintaining the glycolytic pathway in full operation.

There was effect of the $\mathrm{F} \times \mathrm{I}$ interaction $(\mathrm{P}<0.05)$ on $\mathrm{RCI}$, with the average at frequency $95 \% \mathrm{LI}(40.88)$, higher than that of $85 \%$ LI (39.78). This is due to the higher pre-grazing LAI of $95 \%$ LI management when compared to $85 \%$ LI, favoring the higher concentration of chlorophyll pigments that contributed to the increase in the photosynthetic rate of the leaf. Chlorophylls are essential in the photosynthetic process, which is divided in two stages. The first is photochemistry and has the function of capturing atmospheric $\mathrm{CO}_{2}$, the second is biochemistry, which has the role of promoting the biosynthesis of proteins and enzymes resulting from the previous step (Shafiq et al., 2021). Rozalino Santos et al. (2014) characterized the genus Brachiaria as a genus that has high phenotypic plasticity, being able to modify its structure, according to the type of management adopted. These changes occur mainly in the rates of leaf appearance (RLA), leaf senescence (RLS) and stem lengths, thus reflecting on photosynthetic pigments.

The $\mathrm{T}_{\text {Leaf }}$ was affected by the $\mathrm{F} \times \mathrm{I}$ interaction $(\mathrm{P}=0.0092)$, with the management $\left.95 \% \mathrm{LI} \times 1.8\right)$ residual leaf area indexes (RLAI), presenting the highest temperature $\left(34.14{ }^{\circ} \mathrm{C}\right)$, in comparison to the others $(95 \% \mathrm{LI} \times 1.3 \mathrm{RLAI}, 85 \% \mathrm{LI}$ $\times 1.3 \mathrm{RLAI}$ and $85 \% \mathrm{LI} \times 1.8 \mathrm{RLAI}$ ), this behavior may be linked to the lower concentration of starch in the evaluated leaf, which causes the photosynthetic enzymes to act more intensely in that leaf, raising its temperature. 
Table 3. Physiological variables of Brachiaria decumbens 'Basilisk' subjected to two frequencies of light interception (85\% and $95 \% \mathrm{LI})$ and two defoliation intensities (1.3 and 1.8 residual leaf area indexes [RLAI]) in the pre-grazing condition.

\begin{tabular}{|c|c|c|c|c|c|c|c|}
\hline \multirow{3}{*}{ RLAI } & \multicolumn{7}{|c|}{ Leaf liquid photosynthesis rate $\left(\mathrm{A}, \mu \mathrm{mol} \mathrm{CO} \mathrm{Cm}^{-2} \mathrm{~s}^{-1}\right)$} \\
\hline & \multicolumn{2}{|c|}{ LI } & \multirow[b]{2}{*}{ Average } & \multirow[b]{2}{*}{ SEM } & \multicolumn{3}{|c|}{ P-Value } \\
\hline & $85 \%$ & $95 \%$ & & & $\mathrm{~F}$ & I & $\mathrm{F} \times \mathrm{I}$ \\
\hline 1.3 & 22.38 & 23.56 & $22.97 \mathrm{~A}$ & & & & \\
\hline 1.8 & 22.19 & 24.11 & $23.15 \mathrm{~A}$ & 0.3870 & $<0.0001$ & 0.4857 & 0.1684 \\
\hline \multirow[t]{2}{*}{ Average } & $22.29 b$ & $23.84 \mathrm{a}$ & & & & & \\
\hline & \multicolumn{7}{|c|}{ Leaf transpiration rate $\left(\mathrm{E}, \mathrm{mmol} \mathrm{H}_{2} \mathrm{O} \mathrm{CO}_{2} \mathrm{~m}^{-2} \mathrm{~s}^{-1}\right)$} \\
\hline 1.3 & 3.38 & 3.43 & $3.40 \mathrm{~A}$ & & & & \\
\hline 3.38 & 3.43 & $3.40 \mathrm{~A}$ & 3.38 & 0.2058 & 0.0038 & 0.0323 & 0.2058 \\
\hline \multirow[t]{2}{*}{ Average } & $3.39 \mathrm{a}$ & $3.29 \mathrm{~b}$ & & & & & \\
\hline & \multicolumn{7}{|c|}{ Stomatal conductance $\left(\mathrm{Gs}, \mathrm{mol} \mathrm{m}^{-2} \mathrm{~s}^{-1}\right)$} \\
\hline 1.3 & $0.29 \mathrm{Aa}$ & $0.31 \mathrm{Ba}$ & 0.30 & & & & \\
\hline 1.8 & $0.33 \mathrm{Ab}$ & $0.42 \mathrm{Aa}$ & 0.38 & 0.0203 & $<0.0001$ & $<0.0001$ & 0.0044 \\
\hline \multirow[t]{2}{*}{ Average } & 0.31 & 0.37 & & & & & \\
\hline & \multicolumn{7}{|c|}{ Internal $\mathrm{CO}_{2}$ concentration $\left(\mathrm{Ci}, \mu \mathrm{mol} \mathrm{m}{ }^{-2} \mathrm{~s}^{-1}\right)$} \\
\hline 1.3 & 185.25 & 184.70 & $184.98 \mathrm{a}$ & & & & \\
\hline 1.8 & 186.72 & 191.66 & $189.19 \mathrm{a}$ & 6.7733 & 0.3968 & 0.1040 & 0.2878 \\
\hline \multirow[t]{2}{*}{ Average } & $185.99 \mathrm{a}$ & $188.18 \mathrm{a}$ & & & & & \\
\hline & \multicolumn{7}{|c|}{ Internal leaf temperature (Tleaf, ${ }^{\circ} \mathrm{C}$ ) } \\
\hline 1.3 & $33.52 \mathrm{Aa}$ & $33.24 \mathrm{Ba}$ & 33.38 & & & & \\
\hline 1.8 & $33.45 \mathrm{Ab}$ & 34.14Aa & 33.79 & 0.6947 & 0.2617 & 0.0268 & 0.0092 \\
\hline \multirow[t]{2}{*}{ Average } & 33.48 & 33.69 & & & & & \\
\hline & \multicolumn{7}{|c|}{ Relative chlorophyll index (RCI) } \\
\hline 1.3 & $41.22 \mathrm{Aa}$ & $39.06 \mathrm{Bb}$ & 40.14 & & & & \\
\hline 1.8 & $38.33 \mathrm{Bb}$ & 42.71Aa & 40.52 & 1.7610 & 0.0131 & 0.3891 & $<0.0001$ \\
\hline Average & 39.78 & 40.88 & & & & & \\
\hline
\end{tabular}

Means followed by distinct lowercase in the rows and uppercase letters in the columns differ according to the Tukey's test $(\mathrm{P}<0.05)$.

F: Frequency; I: intensity; SEM: standard error of the mean of F $\times$ I.

However, it is worth highlighting the punctual aspect of reading, with the specific environmental factor of the day having an important role in the response of physiological variables. The quality of the light intercepted by the leaves undergoes variation in the atmosphere, mainly due to the inclination of the sun rays; absorption and scattering of part of them; reflection and absorption by the clouds and slope of the receiving surface of these solar rays, interfering mainly in phytochrome. Pezzopane et al. (2015) observed that plants trigger changes of a genetic and metabolic nature in response to environmental stresses and intense management, mainly reflecting on the distribution of the photoassimilates produced.

The frequency and intensity factors did not significantly interfere $(P>0.05)$ in the $\mathrm{C}_{\mathrm{i}}$ variable, that is, the imposed managements were not able to influence the magnitude of use of the $\mathrm{CO}_{2}$ molecules in the mesophyll region, continuing the biochemical process of the photosynthesis.

In general, all the managements adopted (residual and pre-grazing conditions) showed a large production of leaves in the upper strata, up to half the height of the canopy, from which point the stem and dead material accumulation process started.

In the residual condition it was observed that canopies of treatments $85 \% \mathrm{LI} \times 1.3 \mathrm{RLAI}, 85 \% \mathrm{LI} \times 1.8 \mathrm{RLAI}$, $95 \% \mathrm{LI} \times 1.3 \mathrm{RLAI}$ and $95 \% \mathrm{LI} \times 1.8 \mathrm{RLAI}$, in the upper stratum (11 to $20 \mathrm{~cm})$, were basically composed of leaf fraction, in the orders of $77.75 \%, 89.24 \%, 85.85 \%$ and $83.00 \%$, respectively, while in the lower stratum $(0$ to $10 \mathrm{~cm})$ of stem, with the treatments $85 \% \mathrm{LI} \times 1.8 \mathrm{RLAI}, 95 \% \mathrm{LI} \times 1.3 \mathrm{RLAI}$ and $95 \% \mathrm{LI} \times 1.8 \mathrm{RLAI}$, presented $40.61 \%, 44.42 \%$ and $42.00 \%$, respectively. A greater proportion (45.63\%) of the dead material fraction (DFB) was also observed in the treatment 95\% LI × 1.8 RLAI (Figure 2). 
Figure 2. Vertical distribution in residual condition of botanical/morphological components in strata of $10 \mathrm{~cm}$ above the soil surface of Brachiaria decumbens 'Basilisk' submitted to managements of light interception (LI) and residual leaf area indexes (RLAI): $85 \%$ LI $\times 1.3$ RLAI (A), 85\% LI × 1.8 RLAI (B), 95\% LI × 1.3 RLAI (C) and 95\% LI × 1.8 RLAI (D).
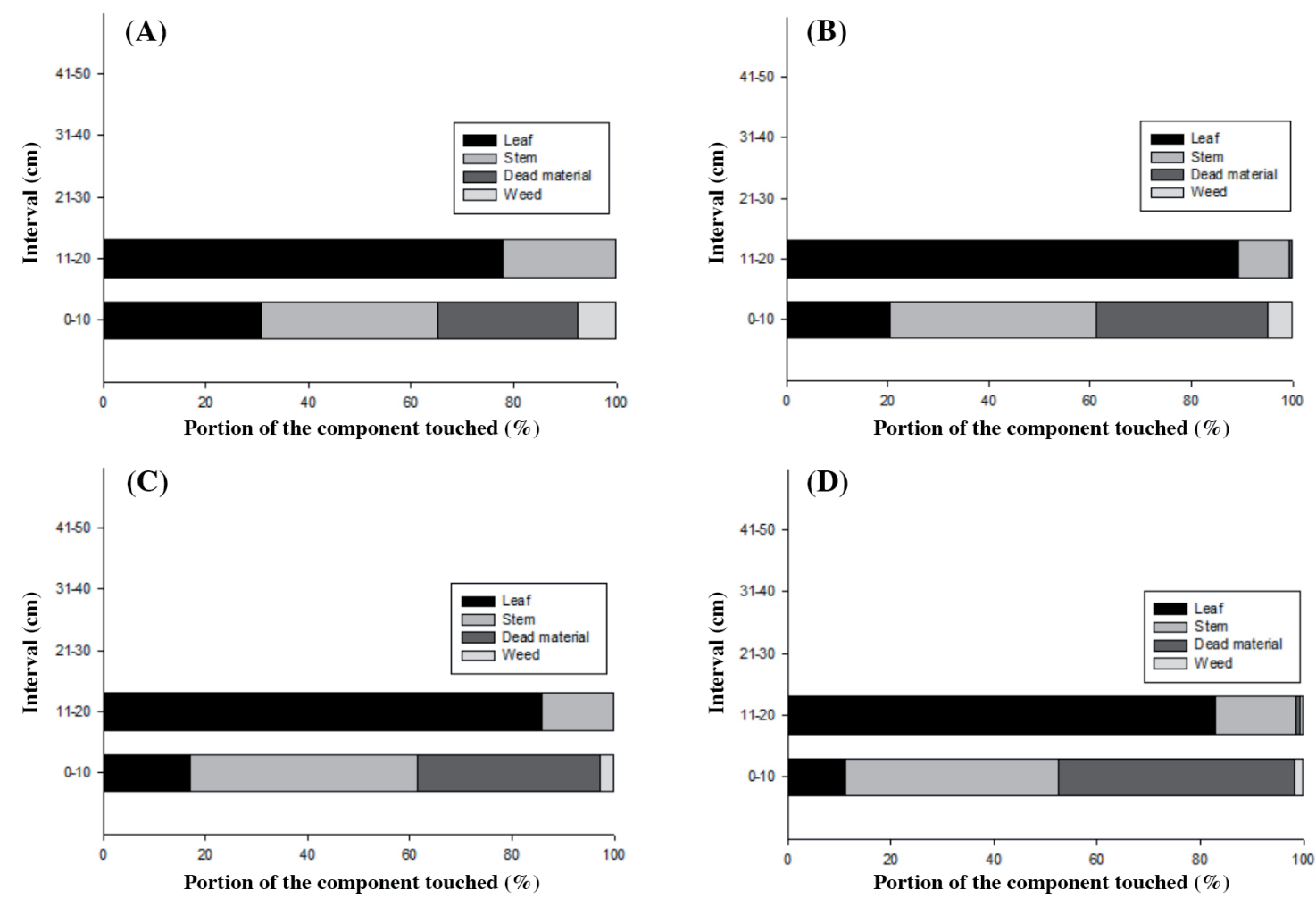

The high accumulations of DFB and GSB in the lower strata (close to the soil surface), are characterized as having low digestibility, which limits intake, thus reducing animal production over time and compromising the pasture's perenniality. Silva et al. (2018) identified in the species Arachis pintoi 'Belmonte', a high relationship between the bite rate and the height variable, having identified a positive intake up to $13 \mathrm{~cm}$ and, from this moment on, a negative linear response of consumption.

In the pre-grazing condition, treatments $95 \% \mathrm{LI} \times 1.3 \mathrm{RLAI}$ and 95\% LI $\times 1.8 \mathrm{RLAI}$ presented higher height when compared to $85 \% \mathrm{LI} \times 1.3 \mathrm{RLAI}$ and $85 \% \mathrm{LI} \times 1.8 \mathrm{RLAI}$, reflected in an extra layer of leaf biomass located from 31 to $40 \mathrm{~cm}$ (Figure 3C and 3D). The managements $85 \% \mathrm{LI} \times 1.3 \mathrm{RLAI}$ and $85 \% \mathrm{LI} \times 1.8 \mathrm{RLAI}$, only reached a height greater than 21 to $30 \mathrm{~cm}$, being constituted of $99 \%$ and $97.00 \%$, respectively, of the leaf fraction. However, a greater presence of the stem fraction was observed in the lower stratum (11 to $20 \mathrm{~cm}$ ) in the order of $64 \%$ and $61 \%$, in treatments $95 \% \mathrm{LI}$ $\times 1.3 \mathrm{RLAI}$ and $95 \% \mathrm{LI} \times 1.8 \mathrm{RLAI}$, respectively, while the managements $85 \% \mathrm{LI} \times 1.3 \mathrm{RLAI}$ and $85 \% \mathrm{LI} \times 1.8 \mathrm{RLAI}$ presented $39.72 \%$ and $36.37 \%$, respectively. With the increase in the resting period, the canopy tends to increase support materials (rich in lignin) at its base, whose main function is to support the weight of the canopy. According to Pereira et al. (2018), B. decumbens grass tends to start its stem deposition way before the critical LAI, with the beginning of the stem elongation rate and deposition of this fraction starting from the $15^{\text {th }}$ day of the rest period.

The $85 \% \mathrm{LI} \times 1.3 \mathrm{RLAI}$ and $85 \% \mathrm{LI} \times 1.8 \mathrm{RLAI}$ managements in the lower layer (0 to $10 \mathrm{~cm}$ ), showed higher leaf production (with greater distribution along the canopy) when compared to managements $95 \% \mathrm{LI} \times 1.3 \mathrm{RLAI}$ and $95 \% \mathrm{LI}$ $\times 1.8$ RLAI, with the values of $9.30 \%$ and $4.68 \%$ being observed, respectively. 
Figure 3. Vertical distribution in pre-grazing condition of botanical/morphological components in strata of $10 \mathrm{~cm}$ above the soil surface of Brachiaria decumbens 'Basilisk' submitted to managements of light interception (LI) and residual leaf area indexes (RLAI): 85\% LI × 1.3 RLAI (A), 85\% LI × 1.8 RLAI (B), 95\% LI × 1.3 RLAI (C) and 95\% LI × 1.8 RLAI (D).
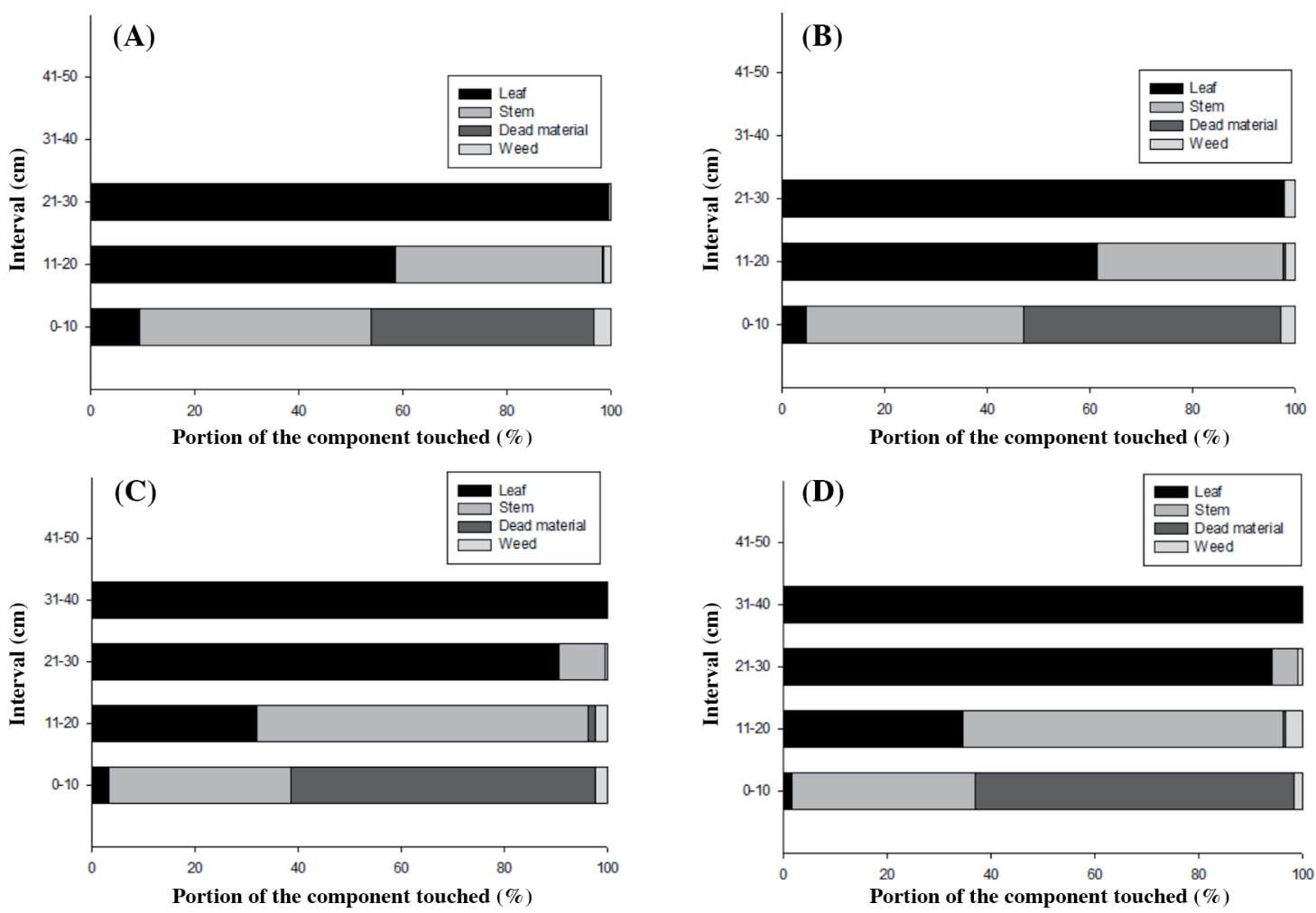

CONCLUSIONS

Production of forage biomass was affected by the management, with leaf, stem and dead material fractions being higher in the pastures that had longer rest periods, as evidenced by the variation in the vertical morphological composition, with the highest defoliation frequency causing reduction in the photosynthetic activity of the plant, with Brachiaria decumbens 'Basilisk' presenting high phenotypic plasticity.

If the objective of the production system that uses B. decumbens 'Basilisk' is to gain per animal, a grazing frequency of $85 \%$ light interception (LI) with 1.8 residual leaf area indexes (RLAI) or 0.49 and 0.85 normalized difference vegetation index (NDVI), respectively, is recommended. Whereas if the objective of the production system is to gain per area, the defoliation frequency of $95 \% \mathrm{LI}$ associated with $1.3 \mathrm{RLAI}$, or 0.44 and $0.88 \mathrm{NDVI}$, respectively, is the most indicated.

\section{ACKNOWLEDGEMENTS}

The authors would like to thank the Coordination for the Improvement of Higher Education Personnel (CAPES) for granting a doctoral scholarship, the Federal University of Ceará (UFC) and the Nucleus for Teaching and Studies in Forage Crops (NEEF) for all the structural and technological support for conducting this research.

\section{REFERENCES}

Alvarez, V.H., de Novais, R.F., de Barros, N.F., Cantarutti, R.B., e Lopes, A.S. 1999. Interpretação dos resultados das análises de solos. p. 25-32. In Ribeiro, A.C., Guimarães, P.T.G., Alvarez, V.H. (eds.) Recomendações para o uso de corretivos e fertilizantes em Minas Gerais. 5a aproximação. Comissão de Fertilidade do Solo do Estado de Minas Gerais, Viçosa, Minas Gerais, Brasil. 
Andersson, K., Trotter, M., Robson, A., Schneider, D., Frizell, L., and Saint, A., et al. 2017. Estimating pasture with active optical sensors. Advances in Animal Biosciences 8:754-757. doi:10.1017/S2040470017000838.

Barthram, G.T. 1986. Experimental techniques - the HFRO sward stick. Biennial Report of the Hill Farming Research Organisation 1984-85. p. 29-30. In Alcock, M.M. (ed.) Hill Farming Research Organisation, Penicuik, Midlothian, UK.

Brougham, R.W. 1956. Effect of intensity of defoliation on regrowth of pasture. Australian Journal of Agricultural Research 7:377-387.

Carvalho, P.C.F. 2013. Harry Stobbs memorial lecture: Can grazing behaviour support innovations in grassland management? Tropical Grasslands - Forrajes Tropicales 1:137-155. doi:10.17138/tgft(1)137-155.

Fialho, C.A., Silva, S.C., Gimenes, F.M.A., Gomes, M.B., Berndt, A., and Gerdes. 2012. Tiller population density and tillering dynamics in marandu palisade grass subjected to strategies of rotational stocking management and nitrogen fertilization. Acta Scientarium 34:245-251. doi:10.4025/actascianimsci.v34i3.13739.

Fonseca, L., Mezzalira, J.C., Bremm, C., Filho, R.S.A., Gonda, H.L., and Carvalho, P.C. de F. 2012. Management targets for maximising the short-term herbage intake rate of cattle grazing in Sorghum bicolor. Livestock Science 145:205-211. doi:10.1016/j.livsci.2012.02.003.

Franklin, K.A. 2016. Photomorphogenesis: plants feel blue in the shade. Current Biology 26(24):PR1275-PR1276. doi:10.1016/j.cub.2016.10.039.

Gastal, F., and Lemaire, G. 2015. Defoliation, shoot plasticity, sward structure and herbage utilization in pasture: review of the underlying ecophysiological process. Agriculture 5:1146-1176. doi:10.3390/agriculture5041146.

Gildersleeve, R.R., Ocumpaugh, W.R., Quesenberry, K.H., and Moore, J.E. 1987. Mob-grazing of morphologically different Aeschynomene species. Tropical Grasslands 21:123-132.

Gomide, C.A.M., Gomide, J.A., e Alexandrino, E. 2007. Características estruturais e produção de forragem em pastos de capim-mombaça submetidos a períodos de descanso. Pesquisa Agropecuária Brasileira 42:1487-1494. doi:10.1590/S0100-204X2007001000017.

Hussain, S., Iqbal, N., Brestic, M., Raza, M.A., Pang, T., Langham, D.R., et al. 2019. Changes in morphology, chlorophyll fluorescence performance and Rubisco activity of soybean in response to foliar application of ionic titanium under normal light and shade environment. Science of the Total Environment 658:626-637. doi:10.1016/j.scitotenv.2018.12.182.

Kroth, B.E., Silva, E.M.B., Silva, T.J.A., Koetz, M., e Schlichting, A.F. 2015. Cultivares de Brachiaria brizantha sob diferentes disponibilidades hídricas em Neossolo Flúvico. Revista Brasileira de Engenharia Agrícola e Ambiental 19:464-469. doi:10.1590/1807-1929/agriambi.v19n5p464-469.

Kumar, R., and Silva, L. 1973. Light ray tracing through a leaf cross- section. Applied Optics 12:2950-2954.

Martins, C.D.M., Schimitt, D., Duchini, P.G., Miqueloto, T., and Sbrissia, A.F. 2020. Defoliation intensity and leaf area index recovery in defoliated swards: implications for forage accumulation. Scientia Agrícola 78:e20190095. doi:10.1590/1678-992X-2019-0095.

Martuscello, J.A., Oliveira, A.B. de, Cunha, D.N.F.V. da, Amorim, P.L. de, Dantas, P.A.L., e Lima, D.A. 2011. Produção de biomassa e morfogênese do capim-braquiária cultivado sob doses de nitrogênio ou consorciado com leguminosas. Revista Brasileira de Saúde e Produção Animal 12:923-934.

Miqueloto, T., Medeiros Neto, C., Martins, C.D.M., Barbosa, R.A., Silva, S.C., and Sbrissia, A.F. 2019. Herbage utilisation efficiency of continuously stocked pasture during periods of restricted pasture growth. Acta Agriculturae Scandinavica, Section B -Soil \& Plant Science 70:208-214. doi:10.1080/09064710.2019.1699157.

Parsons, A.J., Johnson, I.R., and Williams, J.H.H. 1988. Leaf age structure and canopy photosynthesis in rotationally and continuously grazed swads. Grass and Forage Science 43:1-14. doi:10. 1111/j.1365-2494.1988.tb02136.x.

Pedreira, C.G.S., Braga, G.J., and Portela, J.N. 2017. Herbage accumulation, plant-part composition and nutritive value on grazed signal grass (Brachiaria decumbens) pastures in response to stubble height and rest period based on canopy light interception. Crop and Pasture Science 68:62-73. doi:10.1071/CP16333.

Peel, M.C., Finlayson, B.L., and Mcmahon, T.A. 2007. Updated world map of the koppen-Geiger climate classification. Hydrology and Earth System Sciences 11:1633-1644.

Pereira, L.E.T., Herling, V.R., Avanzi, J.C., and Silva, S.C. 2018. Morphogenetic and structural characteristics os signal grass in response to liming and defoliation severity. Pesquisa Agropecuaria Tropical 48(1):1-11. doi:10.1590/1983 40632018v4849212.

Pezzopane, C.G., Menezes Santos, P., Cruz, P.G., Altoé, J., Ribeiro, F.A., e Valle, C.B. 2015. Estresse por deficiência hídrica em genótipos de Brachiaria brizantha. Ciência Rural 45:871-876. doi:10.1590/0103-8478cr20130915.

Pompeu, R.C.F.F., Cândido, M.J.D., Neiva, J.N.M., Rogério, M.C.P., e Facó, O. 2008. Componentes da biomassa pré-pastejo e pós-pastejo de capim-tanzânia sob lotação rotativa com quatro níveis de suplementação. Revista Brasileira de Zootecnia 37:383-393.

Rouse, J.W., Haas, H.R., Schell, J.A., Deering, D.W., and Harlan, J.C. 1973. Monitoring the vernal advancement and retrogradation (green wave effect) of natural vegetation. Progress Report RSC 1978-1. Texas A\&M University, Remote Sensing Center, College Station, Texas, USA.

Rozalino Santos, M.E., Gomes, V.M., e Fonseca, D.M. 2014. Fatores causadores de variabilidade espacial do pasto de capimbraquiária: manejo do pastejo, estação do ano e topografia do terreno. Bioscience Journal 30:210-218. 
Santos, H.G. dos, Jacomine, P.K.T., Anjos, L.H.C. dos, Oliveira, V.A. de, Oliveira, J.B. de, Lumbreras, J.F., et al. (eds.) 2018. Sistema brasileiro de classificação de solos. 5 ed. Embrapa Solos, Brasilia, DF, Brasil.

Shafiq, I., Hussain, S., Raza, M.A., Iqbal, N., Asghar, M.A., Raza, A., et al. 2021. Crop photosynthetic response to light quality and light intensity. Journal of Interactive Agriculture 20:4-23. doi:https://doi.org/10.1016/S2095-3119(20)63227-0.

Silva, L.V., Cândido, M.J.D., Pessoa, J.P.M., Cavalcante, A.C.R., Carneiro, M.S.S., e Silva, A.N. 2015a. Componentes da biomassa e características estruturais em capim-aruana sob diferentes frequências e intensidades de desfolhação. Pesquisa Agropecuária Brasileira 50:1192-1200. doi:10.1590/S0100-204X2015001200009.

Silva, G.P., Fialho, C.A., Carvalho, L.R., Fonseca, L., Carvalho, P.C.F., Bremm, C., et al. 2018. Sward structure and shortterm herbage intake in Arachis pintoi cv. Belmonte subjected to varying intensities of grazing. The Journal of Agricultural Science 156:92-99. doi:10.1017/S0021859617000855.

Silva, S.C., Sbrissia, A.F., and Pereira, L.E.T. 2015b. Ecophysiology of $\mathrm{C}_{4}$ forage grasses - understanding plant growth for optimising their use and management. Agriculture 5:598-625. doi:10.3390/agriculture5030598.

Sollenberger, L.E., Kohmann, M.M., Dubeux Jr., J.C.B., and Silveira, M. 2019. Grassland management affects delivery of regulating and supporting ecosystem service. Crop Science 59:441-459. doi:10.2135/cropsci2018.09.0594.

Wilson, J.W. 1960. Inclined point quadrats. New Phytologist 59:1-7.

Yasuoka, J.I., Pedreira, C.G.S., Silva, V.J., Alonso, M.P., and Silva, L.S. 2017. Canopy height and N affect herbage accumulation and the relative contribution of leaf categories to photosynthesis of grazed brachiariagrass pastures. Grass and Forage Science 73:183-192. doi:10.1111/gfs.12302.

Zanini, G.D., Santos, G.T., Schmitt, D., Padilha, D.S., e Sbrissia, A.F. 2012. Distribuição de colmo na estrutura vertical de pastos de capim-Aruana e azevém anual submetidos a pastejo intermitente por ovinos. Ciência Rural 42:882-887. doi:10.1590/S0103-84782012000500020. 